\title{
THE MEDITERRANEAN DIET: CULTURE AND ITS IMPACT ON CONSUMER HABITS IN BARCELONA RESTAURANTS
}

\author{
La "Dieta Mediterránea": la cultura y su impacto en los hábitos de consumo en restaurantes \\ de Barcelona
}

Javier Sánchez-Torres

Master Business Research, Universidad de Barcelona, Barcelona-España, jasanchto19.alumnes@ub.edu

Francisco-Javier Arroyo-Cañada

PhD Business, Universidad de Barcelona, Barcelona-España, fjarroyo@ub.edu

\section{María-Lluisa Solé-Moro}

PhD Ciencias Económicas y Empresariales, Universidad de Barcelona, Barcelona-España, mlsolesole@ub.edu

\section{Ana Argila-Irurita}

PhD Business, Universidad de Barcelona, Barcelona-España, aargila@ub.edu

\section{Cómo citar / How to cite}

Sánchez-Torres, J., Arroyo-Cañada, F.J., Solé-Moro, M.L. y Argila-Irurita, A. (2017). The mediterranean diet: culture and its impact on consumer habits in Barcelona restaurant. Revista CEA, 3(6), 47-54.

Recibido: 10 de abril de 2017

Aceptado: 30 mayo de 2017

\section{Abstract}

This article studies the importance of the Mediterranean diet in the menus of restaurants in the city of Barcelona. It is based on a review of previous studies about the great influence of the Mediterranean culture on daily aspects such as food. A qualitative study was conducted and a sample of experts-head chefs at restaurants in Barcelona-was selected. The results show that the Mediterranean diet is positioned in the minds of their customers; therefore, all the decisions related to the purchase of products and the planning of menus and dishes are made following the guidelines of the Mediterranean diet. This study is an important contribution to the research field of culture in consumption habits, because it confirms that the Mediterranean diet still is strongly preferred over new foods, dishes and foreign menus. The habits of consumers remain true to their culinary traditions.

Keywords: mediterranean diet, Barcelona, culture, consumption.

\section{Resumen}

Este artículo se ha enfocado en estudiar la prevalencia de la dieta mediterránea en los menús de los restaurantes de la ciudad de Barcelona, partiendo de una revisión de estudios previos referentes a la gran influencia de la cultura "Mediterránea" sobre aspectos diarios como lo es la alimentación. Se ha 
establecido un estudio cualitativo seleccionando una muestra de expertos, definida por jefes de cocina de los restaurantes barceloneses. Los resultados evidencian que la dieta mediterránea está posicionada en la mente de sus clientes y por tanto genera que todas las decisiones de compra de insumos, planificación de minutas, elaboración de platos y menús, se realicen siguiendo los lineamientos de la dieta mediterránea. Este estudio es un aporte de gran importancia para la línea de investigación sobre la cultura en los hábitos de consumo especialmente con la dieta mediterránea, ya que, confirma que su prevalencia frente a nuevos alimentos, platos y menús foráneos es fuerte y los hábitos de los consumidores se mantienen fieles a sus tradiciones culinarias.

Palabras clave: dieta mediterránea, Barcelona, cultura, consumo.

\section{INTRODUCTION}

Globalization is a phenomenon that, in recent years, has generated changes in the consumption and diet of populations around the world due to the incorporation of regional foods into a global market (Askegaard \& Madsen, 1998). This has affected all the actors in the value chain (Meiselman, 2017) and consumers have experienced most changes according to Méndez (2014). Two major changes have occurred worldwide in the food culture. First, supply and the free market have improved the access of most part of society to a varied and balanced diet, while the global food supply has generated the loss of one's own food culture as the homogenization of eating habits crosses borders (Küster-Boluda \& Vidal-Capilla, 2017). Secondly, all phenomena related to food-such as risks, legislation, social norms and trends-are ever-present and affect consumption habits (Jallinoja, Niva, \& Latvala, 2016). In Europe and especially in the
Mediterranean, there are a number of habits and tastes in consumption called the "Mediterranean diet".

Against this background, food culture in Spain has generally maintained its traditions, even as a "shared culture" has been generated by the consumption of foods belonging to the socalled "Mediterranean diet" combined with new habits resulting from globalization. One of the most important characteristics of this diet is that it maintains the tradition of eating products made from fresh produce at home (Benedetti, Biggeri, Laureti, \& Secondi, 2016). Furthermore, the increase in obesity, sedentary lifestyle and chronic diseases-such as diabetes or hypertension-in the population has caused one in four Spaniards to have to follow a diet under medical prescription, which has had a positive influence on the consumption of the Mediterranean diet (Méndez, 2014).

In Spain, the Mediterranean diet has been inherited by the young, according to the studies by Fernández-Puertas (2014). Their results show that $70 \%$ of a sample of Spanish college students maintained an average adherence to this tradition in food consumption, and $20 \%$ maintained a strong adhesion to regional foods such as olives, cured cheese, nuts and seeds, among others. Consumers buy products from their region because they are healthy and taste good, and they associate these qualities with the Mediterranean diet (Fernández-Puertas, 2014). Likewise, such diet is supported by intermediate distribution and local shops, thus meeting the needs of those who desire to consume food and products associated with it (Méndez, 2014).

However, the eating habits of Spaniards present negative factors such as modern lifestyles that substitute the consumption of the traditional diet with "fast food", which can 
generate significant changes in the Spanish diet. Faced with this situation, the influence of the Mediterranean food can prevail (DíazMéndez \& García-Espejo, 2016) because culture establishes social norms, individual needs, motivations and consumer values (Petruzzellis \& Craig, 2016). The consumer is then more sensitive to the cultural characteristics of foods (Cannon, 2005).

Therefore, the opportunity arises for food producers-whether restaurants, manufacturers of prepared foods or distributors - to offer food under the Mediterranean diet standards as a differentiating strategy (Petruzzellis \& Craig, 2016).

They could also produce foodstuffs with characteristics of the Mediterranean diet, especially in pre-cooked, canned, preserved and prepared food (Varela-Moreiras, Ruiz, Valero, Ávila, \& Pozo, 2013).

In this context, the objective of this article is to examine whether the culture of the Mediterranean diet affects the decision making of chefs at hotels and restaurants in the catering industry-called Horeca in Europeand, more specifically, whether chefs make their menu-planning decisions based on the Mediterranean diet.

\section{Culture and food consumption}

Culture includes all facets and social traits associated with a country, group of countries, or region, related to the existing traditions that characterize the peoples (Minkov and Hosftede, 2014). There are studies that relate the orientations in food consumption to the influence of culture (Davis, Wang, \& Lindridge, 2008; Kyunghee, Donghoon, \& Jungmin, 2013; Rozin, Kurzer, \& Cohen, 2002). For example, considering the form of affectation in individuals depending on the social characteristics of their culture, the theory of cultural self-regulation establishes that culture has an effect on the emotions and behaviors of the consumer. Davis et al. (2008) compared this effect between collectivist cultures (China) and individualistic cultures (United States); they found that people in collectivist cultures tend to be more sensitive to the emotions and perceptions of members of their culture for making decisions. Specifically regarding food consumption, studies show that the culturally and congruent component of tradition generates a positively high response in the choice of traditional or ethnic food in the region (Kyunghee, Donghoon, \& Jungmin, 2013).

Other research further specifies the influence of different cultures on the eating habits of their members; for example, consumers in the Philippines and China are most affected by mood (Januszewska, Pieniak, \& Verbeke, 2011). Japanese culture exerts a strong influence on the diet choice; as a result, they prefer varied dishes in small portions based on the sensory attributes of food that attends to their adventurous taste (Freedman, 2016).

\section{The mediterranean culture and its influence on food consumption}

The Mediterranean culture is a set of elements and values derived from diverse geography, history and ethics. Consequently, the Mediterranean people present a duality: on the one hand, a strong sense of belonging to their home and traditions that generates a powerful emotional influence; but, on the other hand, the feeling of freedom with a high degree of uprooting (Petruzzellis \& Craig, 2016).

Around the Mediterranean area, food is included in the culture, as identity and traditions are represented by products, foods, flavors, smells, colors and other characteristics of the Mediterranean diet. Such characteristics are present in at least 16 countries bordering 
the Mediterranean Sea. Their diets slightly vary depending on the cultures of each country but, in general, they are within a framework of ethnic origin and traditional agricultural production that generates the consumption of local fruits and vegetables, cereals, potatoes, legumes, nuts and seeds, olive oil, fish, poultry, small amounts of red meat, eggs, and wine in moderate amounts (Jiménez-Beltrán, LópezGuzmán, \& Santa Cruz, 2016).

Some research has shown that food culture has a direct influence on consumer buying behavior. For example, in the study by Cacciolatti, Garcia \& Kalantzakis (2015) of the marketing of feta cheese of Greek appellation of origin in the United Kingdom, consumers valued product features and designation of origin as factors influencing their purchase decision (Bazzani, Caputo, Nayga Jr, \& Canavari, 2017).

More specifically, regarding the effect of local culture on food consumption, the study by Molnár, Gellynck, Vanhonacker, Gagalyuk, \&Verbeke (2011) confirms that consumers look for products related to their traditional character. Thus, maintaining the authentic recipe helps a product be well received by the consumer. As a result, the "Mediterranean diet" brand is a competitive strategy that allows producers of pre-cooked and packaged foods to be positioned, not only with local consumers, but also in foreign markets where the brand has penetrated (Fort, 2012).

\section{METHODS}

To address the question of this research, a qualitative approach has been chosen in order to understand the perspective of the cooks regarding the Mediterranean diet, since this technique allows for a deeper understanding of how participants perceive reality (Denzin \& Lincon, 2005).
The design of this study is phenomenological (Kornbluh, 2015; Salgado Levano, 2007) since the goal is to answer the research question from the point of view of the experience of the cooks. Besides, the parameters of the interview were structured with closed-ended questions in order to establish codes of analysis so that the results can answer the proposed question (Drisko, 2005).

\section{Sample, data collection and results}

The sample was defined by considering the population in the geographical area of Barcelona, which was later narrowed down to head chefs at hotels and restaurants in the city. For this purpose, a homogeneous sampling methodology was determined: between 40 and 50 experts who accepted to be interviewed (Denzin \& Lincon, 2005). The data collection period was 2015; in all cases, the visits and interviews were conducted with each chef. A list of restaurants in each zone was made and physical visits were randomly conducted in the first stage, during which the head chefs were asked if they wanted to participate in the study. In case of acceptance, we proceeded to conduct the interview. An initial sample of 65 experts (chefs) agreed to participate in the study; out of these, 42 chefs constituted the final sample.

The interview questions focused on inquiring about the importance of the menu of the Mediterranean diet in their daily work with restaurant menus. A question about the incorporation of foreign ingredients or changes in the menus related to new lifestyles was included as well. The Kendall test was applied to ensure that the answers of the experts had an acceptable degree of concordance and the results were satisfactory (Salgado Levano, 2007) (Table 1). 
Table 1. Kendall's coefficient of concordance Tabla 1. Coeficiente de concordancia de Kendall

\begin{tabular}{ll} 
N & 5 \\
Kendall's W & 0.621 \\
Chi-squared & 127,337 \\
Df & 41 \\
Sig & 0.000 \\
\hline
\end{tabular}

Source: Author's own work, results of the analysis on the SPSS software.

\section{RESULTS}

Once the interviews were transcribed, we obtained the following results:

\section{The Mediterranean diet and the Spanish cooks}

Regarding the first question, "Do you take the Mediterranean diet into account when preparing the weekly menu?", a total of 40 experts responded that they do take into account the Mediterranean diet when they prepare their weekly menus; only 2 experts said they did not take it into account.

To the second question, "To what extent do you think that it is important to people that restaurants adapt their daily menus to the Mediterranean diet?", 25 of the expert interviewees replied that the Mediterranean diet is considered "very important" and 13 experts deemed it "quite important". At the other end of the scale, only 3 experts regarded it as unimportant and one considered it to be neither very significant nor insignificant.

In the next section of the interview the experts had to choose, between two options, the statement they felt more identified with when planning their menus:

"Customers are increasingly concerned about diet and prefer healthy natural products on the menu." versus

"Customers have the same concern as always; they eat varied food and don't think so much if it's healthier or more natural."

Given these two statements, a total of 38 experts agreed with the first position and only 4 experts identified with the second sentence. Therefore, their perception is that their customers give very much importance to dishes associated with the Mediterranean diet, especially in relation to the healthy aspects of food preparation and dishes.

"I have changed the items on the menu in recent years to adapt it to a more Mediterranean style of diet."

versus

"I plan almost the same menus as always, without adapting them to a Mediterranean diet."

With this second choice of statements we wanted to delve a little more in the influence of the Mediterranean diet on the way of cooking in previous years. We found that 34 of the cooks identified with the first circumstance and 8 of them, with the second one. It is therefore shown that a vast majority of experts have adapted their menus to the style of the Mediterranean diet in recent years.

"The three-course composition-appetizer, main course and dessert/coffee-is practically universal."

versus

"People increasingly demand lighter dishes and, even more frequently, one-course meals." With these last two statements to choose from we wanted to know if new lifestyles have modified the classic Mediterranean threecourse composition-appetizer, main course and dessert/coffee-and if customers demand lighter dishes or one-course meals to save time, money, or adopt foreign fast-food cultures. Faced with this, 25 experts considered that the composition of the traditional Mediterranean 
meal is maintained, and the remaining 17 believe that diners tend more to demand lighter dishes or even one-course meals.

Based on these results, the eating habits of people in Barcelona can be considered to be changing and new ones are gaining ground. $A$ one-course meal does not necessarily mean a breakaway from the Mediterranean diet, but the traditional menu may also be displaced due to social and cultural factors such as rhythms of work, budget and foreign diets (fast food), among others.

In the last section of the interview, we went deeper into specifying what dishes the cooks associated with the Mediterranean diet. We asked the experts whether they considered paella as the most representative dish of the Spanish Mediterranean menu. With respect to this, 24 experts said "Yes"; the remaining 18, "No". Those 18 were then asked what dish they did consider to be the most representative. In this regard, 6 selected vegetables; 4, fish; 4, salads; 3 , gazpacho; and 1, broth.

\section{DISCUSSION AND CONCLUSIONS}

This article aimed to explore whether the culture of the Mediterranean diet affects the choice of ingredients of head chefs in the product distribution channel to hotels, restaurants, and catering companies (Horeca) in the city of Barcelona. Specifically, the study sought to determine: a) if Spanish chefs prefer the Mediterranean diet as way of planning their recipes because of the demand of their customers, and b) if Spanish chefs prefer to buy products that are made based on the concept of Mediterranean diet and labeled with a Mediterranean designation of origin.

Almost all the experts in the sample stated that their customers demanded menus in line with the guidelines of the Mediterranean diet and that all the decisions regarding the preparation of their dishes revolved around this. Therefore, it can be assumed that such diet closely governs their food purchases and preparations; that is, the chef will value those suppliers who offer products with characteristics of the Mediterranean diet, both in designation of origin (grown in the region) and labels associated with the Mediterranean brand. Also, traditional products such as paella, vegetables, fresh salads, fish, seafood, gazpacho and broths are considered to be elaborate dishes representative of the Mediterranean diet with great demand and acceptance by consumers (Díaz-Méndez \& García-Espejo, 2016).

In conclusion, the Mediterranean diet is made up of a collection of preferences affected by the current culture in the Mediterranean area of Barcelona. Such culture is composed of the traditional food habits of the region, which composed of the typical ingredients of the Mediterranean diet. On the other hand, cultural changes generated by globalization, the digital age and the new rhythms of work have modified food consumption habits, portions and devoted time. As a result, there are places where the demand for dishes that conserve the traditional ingredients is hampered by a desire for quick dishes, smaller portions, semi-prepared food and/or takeout options.

Future lines of research are suggested to examine such factors on each component of the food value chain to establish if there is indeed a significant influence of culture and cultural change on a population's eating habits. Finally, it is necessary to analyze if regional cultures are permeable to foreign customs that can transform or modify the local nutritional habits. 


\section{REFERENCES}

Askegaard, S., \& Madsen, T. K. (1998). The local and the global: exploring traits of homogeneity and heterogeneity in European food cultures. International Business Review, 7(6), 549-568.

Bazzani, C., Caputo, V., Nayga Jr, R. M., \& Canavari, M. (2017). Revisiting consumers' valuation for local versus organic food using a non- hypothetical choice experiment: Does personality matter?. Food Quality and Preference, 62(7), 144154.

Benedetti, I., Biggeri, L., Laureti, T., \& Secondi, L. (2016). Exploring the Italians Food Habits and Tendency towards a Sustainable Diet: The Mediterranean Eating Pattern. Agriculture and Agricultural Science Procedia, 8, 433-440.

Cacciolatti, L. A., Garcia, C. C., \& Kalantzakis, M. (2015). 'Traditional Food Products: The Effect of Consumers' Characteristics, Product Knowledge, and Perceived Value on Actual Purchase". Journal of International Food \& Agribusiness Marketing, 27(3), 155-176.

Cannon, J. (2005). Notions of region and the Mediterranean diet in food advertising: Quality marks or subjective criteria?. British Food Journal, 107(2), 74-83.

Davis L., Wang S., \& Lindridge, A. (2008). Culture influences on emotional responses to on-line store atmospheric cues. Journal of Business Research, 61, 806-812.

Denzin, N. K., \& Lincon Y.S. (2005). The Stage handbook of Qualitative Research (3a, Ed.), London, Stage Publication.
Díaz-Méndez, C., \& García-Espejo, I. (2016). Eating out in Spain: Motivations, sociability and consumer contexts. Appetite, 119, 1422.

Drisko, J. (2005). Writing up qualitative research. Families in society. The journal of contemporaty social services, 86, 589-593.

Fernández-Puertas, N. (2014). Adherencia al patrón de dieta mediterránea en un grupo de estudiantes universitarios. ValladolidEspaña, Universidad de Valladolid.

Fort, F. (2012). Traditional Mediterranean products: markets and large-scale retail trade. In Mediterra 2012. (pp. 305-324). Presses de Sciences Po (PFNSP).

Freedman, I. (2016). Cultural specificity in food choice - The case of ethnography in Japan, Appetite, 96, 138-146

Januszewska, R., Pieniak, Z., \& Verbeke, W (2011). Food choice questionnaire revisited in four countries. Does it still measure the same?. Appetite, 57(1), 94-98.

Jallinoja, P., Niva, M., \& Latvala, T. (2016). Future of sustainable eating? Examining the potential for expanding bean eating in a meat-eating culture. Futures, 83, 4-14.

Jiménez-Beltrán, F. J., López-Guzmán, T., \& Santa Cruz, F. G. (2016). Analysis of the relationship between tourism and food culture, Sustainability, 8(5).

Küster-Boluda, I., \& Vidal-Capilla, I. (2017). Consumer attitudes in the election of functional foods. Spanish Journal of Marketing - ESIC, 21, 65-79.

Kornbluh, M. (2015). Combatting Challenges to Establishing Trustworthiness in Qualitative 
Research. Qualitative Research in Psychology, 12 (4), 393-414.

Kyunghee, B., Donghoon, K., Jungmin, S., (2013). Is the culture-emotion fit always important?. Journal of Business Research, 66 (8), 983-988.

Logue, A. W., \& Smith, M. E. (1986). Predictors of food preferences in adult humans.

Appetite, 7(2), 109-125.

Meiselman, H. L. (2017). An Historical Perspective on variety in United States dining based on menus. Appetite, 118(1), 174-179.

Méndez, C. D. (2014). Hábitos alimentarios de los españoles: Cambios en las maneras de vivir, comprar y comer. Distribución y consumo, 24(135), 20-29.

Minkov, M., \& Hofstede, G. (2014). A replication of Hofstede's uncertainty avoidance dimension across nationally representative samples from Europe. International Journal of Cross Cultural Management, 14(2), 161-171
Molnár, A., Gellynck, X., Vanhonacker, F., Gagalyuk, T., \& Verbeke, W. (2011). Do chain goals match consumer perceptions? The case of the traditional food sector in selected European Union countries. Agribusiness, 27(2), 221-243.

Petruzzellis, L., \& Craig, C., S. (2016). Separate but together: Mediterranean identity in three countries. Journal of Consumer Marketing, 33(1), 9-19.

Rozin, P. (1982). Human food selection: The interaction of biology, culture and individual experience. In the psychobiology of human food selection (pp. 225e254).

Rozin, P., Kurzer, N., Cohen, A., B. (2002). Free associations to "food:" the effects of gender, generation, and culture. Journal of Research in Personality, 36(5), 419-441.

Salgado Lebano, C. (2007). Investigación cualitativa: Diseños, evaluación del rigor metodológico y retos. Liberabit, 13, 71-78.

Varela-Moreiras, G., Ruiz, E., Valero, T., Ávila, J., M., \& Pozo, S., D. (2013). La dieta española: una actualización. Nutrición Hospitalaria, 28, 13-20. 